\title{
CARTOGRAPHY AND AERIAL PHOTOGRAPHY
}

UDC 528.9.72.11

\author{
Ludmyla KAZACHENKO ${ }^{1}$, Vladyslav KAZACHENKO ${ }^{2}$, Tetyana ZHIDKOVA ${ }^{3}$ \\ ${ }^{1}$ Kharkiv National Automobile and Road University, 25, Yaroslava Mudroho Str., Kharkiv, 61002, Ukraine, \\ https://orcid.org/0000-0001-7188-2790, e-mail: fop.kazacenko@gmail.com), tel. +38 (067)-309-709-3 \\ ${ }^{2}$ Kharkiv National University of Municipal Economy, 17, Marshal Bazhanov Str., Kharkiv, 61002, Ukraine, \\ e-mail: kaza4enko.vlad@gmail.com, tel. +38 (095)-866-30-85 \\ ${ }^{3}$ Kharkiv National University of Municipal Economy, 17, Marshal Bazhanov Str., Kharkiv, 61002, Ukraine, e-mail: tavlz@ukr.net, \\ id orcid 0000-0001-7903-7073, tel. +38 (067)-570-41-50
}

https://doi.org/10.23939/istcgcap2021.94.029

\section{GIS TECHNOLOGIES AND 3D SIMULATION IN MAPPING MANIFESTATION OF EXOGENIC PROCESSES IN RENEWABLE TERRITORIES}

The development of exogenous processes on the Earth's surface is a large-scale problem. Due to the development of exogenous processes there are changes in the composition and structure of the earth's crust and its surface. The destruction of streets, houses and public buildings, roads and railways leads to enormous losses. To predict the development of soil degradation, erosion processes on agricultural lands, which lose annual production areas, leads to the formation of a ravine-beam system and reduces the productive amount of land owned by citizens - is a solution. The use of GIS technologies, remote sensing of the Earth and modern programming can partially solve the problem, as it is a rapid identification of areas that have undergone the process of soil degradation and possible prediction of the development of negative phenomena. The use of geodetic software, GIS, information layers of the Public cadastral map can help in the fastest finding of territories, development of the forecast of the further destructive action, development of the corresponding protective methods and their introduction. The areas with manifestations of exogenous processes - soil degradation in agricultural enterprises, where every year the area of highly fertile chernozems is lost, which leads to large losses and landslides in the forest-steppe and steppe settlements of Kharkiv region have been subject of our study. We investigated destructive processes by geodetic measurements in the territories of their manifestations, observations were carried out for 8 years. The development of exogenous processes on the Earth's surface was revealed, which was manifested in landslides in the settlements of the forest-steppe zone and degradation of agricultural lands in the steppe and forest-steppe part of Kharkiv region. The cause of the destruction of the earth's surface were factors independent of human activity. We built 3D models of development of exogenous processes manifested in soil erosion and growth of the ravine-beam system and determined the degree of erosion after surveying and processing the results of geodetic measurements in the software Digitals. For 8 years, we made changes to the software, surveying the area and building a monitoring line. Also in the settlements on the territory of the two zones, we observed the development of landslides on the streets of the village. s. Milova and Nova Vasylivka, where there is an intensive development of exogenous processes. The use of GIS technologies and remote sensing of the Earth to monitor the development of exogenous processes simplifies the solution.

Key words: GIS technologies, remote sensing, regenerated areas, soil degradation, exogenous and endogenous processes, spatial data, destruction.

\section{Introduction}

The problem of development of exogenous processes, destruction of soil cover is one of the problems of mankind. Allocation of such territories, prevention of their development in modern conditions of economic activity is possible due to the use of modern geographic information systems (GIS) and remote sensing of the Earth (remote sensing) from outer space. Information about the development of exogenous processes can help stop such phenomena and prevent the destruction of the earth's surface. It is possible to predict the development of destructive processes on the earth's surface with timely information and modern means - GIS and remote sensing, so it is possible to build development models and predict further development of soil destruction processes, which may affect management decisions.

Analysis of recent research and publications. The problems of soil destruction are investigated by many scientific researchers who have proved that the destruction of the earth's surface is influenced by anthropogenic load, irrational conducting commodity agricultural production, noncompliance with crop rotations, relief and climate conditions [Kuznetsov, et al., 2005; Rudko, 1995], heavy rains, excessive mining [Lushchyk, et al., 2005]. The physical degradation of soils is influenced [Barthelmes, 2012; Bektaş, 2015] by the size of raindrops and the intensity of heavy rains and melting snow [Medvedev, 2013; Pylypenko, et al., 2004; Zaslavsky, 1983; Kryvov, 2006], excessive plowing of agricultural lands leads to the development of soil erosion [Medvedev, 2013; Pylypenko, et al., 2004]. But human activity does not lead to the destruction of the earth's surface [Close, 2010], it is the action of completely different processes - exogenous, and for the restored areas require their definition and mapping. Exogenous processes have a negative impact on the environment, landslides in settlements destroy houses, roads and other linear engineering structures [Tserklevych, et al., 2017, 2018]. With the help of GIS-technologies it is possible to map the negative effects of these processes and predict their spread with the help of modern geographic information systems [Kazachenko L. M., Kazachenko D. A., 2018; Rogister, 2009].

Presentation of the main material. The main destructive forces that change the composition and structure of the earth's surface are geodynamic processes, under the influence of which the Earth's surface collapses, there are earthquakes, volcanic eruptions, shallowing of the oceans, rocks are formed. All these processes are in a dialectical relationship and occur continuously, conditioning and changing each other, which 
ensures the evolutionary development of all living and nonliving things on our planet. Within both the outer and inner geospheres, our planet has changed continuously, changes have occurred and are occurring in its composition, physical state, appearance, position in space and in relationships with other components of the solar system. At the time of the formation of our planet due to the development of complex processes of condensation of matter was the formation of the shape of the Earth as an ellipsoid of rotation. The relationship of forces that still function today in the globe and in its outer geospheres, forms geodynamic processes. This is the mutual attraction of the particles of matter that make up the globe; gravitational forces of interaction between the Earth, the Moon, the Sun and other planets; rotational forces, i. e. forces associated with the rotation of the Earth around the axis and the change in speed of this rotation; forces that arise in the body of the inner geospheres as a result of changes in the temperature of the planet, i.e the temperature of the Earth's interior; forces, the source of which is the chemical transformation of matter in the bowels of the planet, as well as changes in the physical state of matter under conditions of high temperatures and pressures; forces associated with the external influence on Earth of other cosmic bodies and, especially the Sun, which with the help of thermal energy and solar wind, drives water and air masses, i. e. directly affects the state of the hydrosphere and atmosphere, and determines the state biosphere. All the above forces acting in the outer and inner geospheres of the Earth, determine its dynamics - various transformations, according to the laws of the dialectic of nature. All processes are divided into processes of internal dynamics - endogenous, and processes of external dynamics - exogenous, depending on the source that causes them.

The aim of the study was to identify the manifestations of exogenous processes in the areas of residential and public development of settlements of the forest-steppe and steppe part of Kharkiv region using modern geographic information systems and remote sensing data of the Earth. To find out the causes and consequences of exogenous destructive processes and probably to predict the further development of the destruction of the Earth's surface by modeling. Rapid identification of areas that have undergone the process of soil degradation and forecasting the development of negative phenomena is possible with the use of GIS technologies and remote sensing. So we wanted to compare different areas of the forest-steppe and steppe zone of Kharkiv region for the development of exogenous processes, to identify the causes and consequences. In the Kharkiv region, deposits with the ability to karst are spread over an area of 31.34 thousand $\mathrm{km} 2$ $(99.8 \%)$. The development of the karst formation process is not typical for the territory of the region. In the valleys of the Siv.Donets and Vovcha rivers, in the conditions of shallow Cretaceous deposits, karst funnels with a diameter of 10.0-30.0 $\mathrm{m}$ are observed. The total number of karst manifestations is 11 , and 5 manifestations of paleokarst are noted [Zaslavsky, 1983; Kryvov, 2006]. Observations revealed an increase in the anthropogenic factor - uncoordinated excavation of landslides, exposure of landslides - burning of vegetation, felling of trees, mowing of grass.

\section{Research methodology}

Fig. 1 presents a raster map of the study area - Milova village council of Balakliia district.

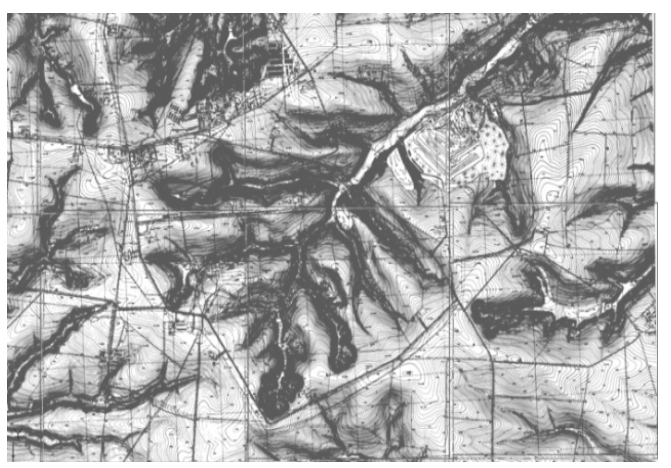

Fig. 1. Raster map of Milova village council

The raster map of the territory shows the danger of erosion, the development of exogenous processes - landslides on the territory of Milova village council on the streets of Milova, Krynychne, Pervomaiske, Pyatigirske villages.

The raster map shows that the territory of Milova village council is affected by the development of exogenous processes. Figure 2 shows a space image of the same area, which shows the development of exogenous processes. In the upper right corner is Milova village, on the south-western side is a quarry for the extraction of minerals - chalk (white chalk deposits and quarry boundaries).

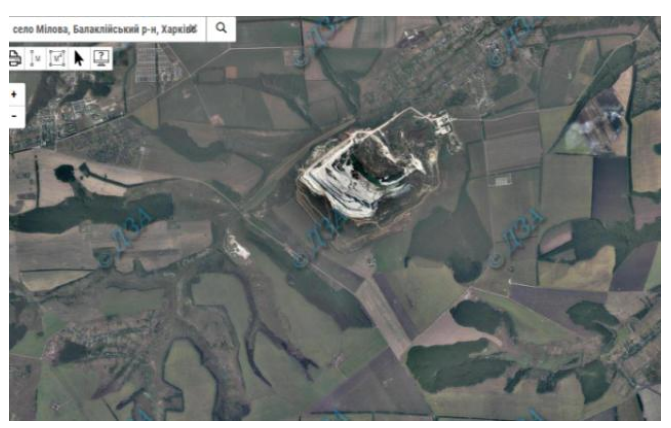

Fig. 2. Space image of the study area

Raster map and space image gives an idea of the development of exogenous processes - landslides, soil erosion, karst deposits. In the materials [Activation of dangerous exogenous processes in Ukraine, 2020; Muratova, 2020] noted that the effect of exogenous processes has spread on the territory of Ukraine, in particular in the Kharkiv region and on the territory of the Milova village council of the Balakliia district. According to these materials, it is noted that in the Kharkiv region the development of exogenous processes (EGP) continues, there are a total of 1615 landslides on an area of $40.3 \mathrm{~km}^{2}$, affected $0.13 \%$, karst -11 on an area of $31340.0 \mathrm{~km}^{2}$, affected $99.8 \%$, loess soils capable of subsidence -66.3 , with an area of $20840.0 \mathrm{~km}^{2}$. Part of the EGP falls on the territory of Milova village council. In Milova village action of exogenous processes is developed on the ravine-beam system, there are 26 landslides, the action of which threatens the gas distribution system and gas wells, threatens agricultural lands - due to the 
development of the ravine-beam system the area of arable lands is reduced (Fig. 3).

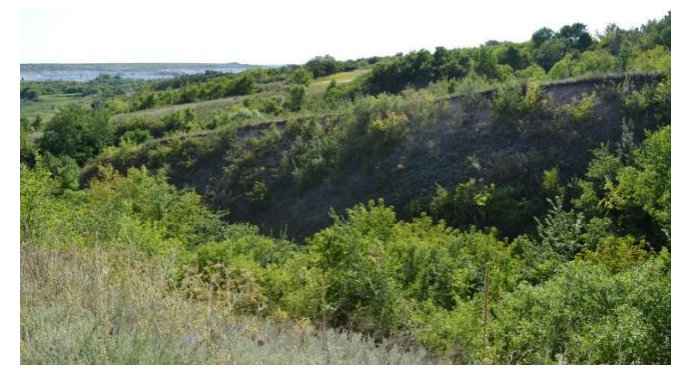

Fig. 3. Photo of the development of EGP, which destroys the village

In case of intensification of landslides, part of residential buildings on Vysoka and Pidlisna streets may be destroyed. Part of the landslides, on the right slope of the river Siverskiy Donets, where the village is located. Milova, is a threat not only to private homes, but also to roads and public buildings, many 5-storey apartments. Also under the influence of landslides there is a constant reduction in the area of homesteads. As a result of the study, it was found that the local activation was manifested in one form on the left side of the Milovatka beam. To identify areas with manifestations of exogenous processes remote sensing data from space images were used (Fig. 2), Public cadastral map (Fig. 4).

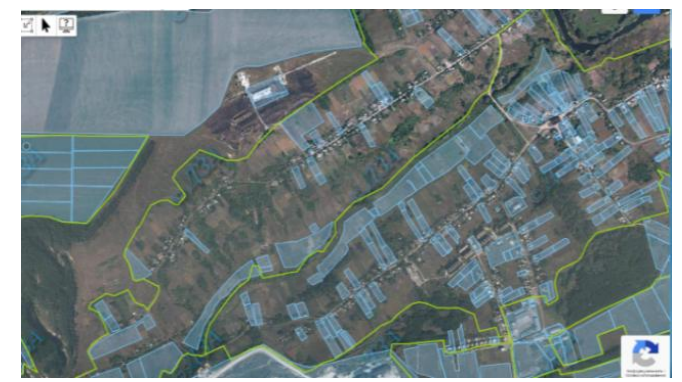

Fig. 4. Milova on the Public cadastral map

We studied the destruction of the earth's surface by geodetic measurements, 2 times a year we went to the location of landslides and conducted research - filmed the boundaries of landslides, coordinated with a single frequency GPS-receiver of the manufacturer - Trimble. The results were recorded on a computer, processed and stored. When solving problematic issues related to landslides within settlements, when almost the entire street is shifted, urgent management decisions are needed, so timely information and modeling of development is needed. We found a rapid shift during the land survey of Milova village, Balakliya district, Kharkiv region.

\section{Results}

Analyzing the situation, we can note the following: the village of Milova, Balakliia district, Kharkiv region, is in a zone of various negative influences of anthropogenic origin, firstly: in the village there is an active quarry for the extraction of minerals - chalk. The product is open and closed methods at different depths. Chalk on the pipeline under high pressure is sent to the company OJSC "Baltsem", which manufactures chalk products, cement and slate. There used to be chalk mountains here, at the time of the landslide research there is a large pit and part of the chalk mountains, which have not yet been developed for quarrying.

The soils of the village are mainly loamy and clayey, which by their mechanical composition are heavy and moisture-absorbing and therefore slippery. The village of Milova is located on the border of the Siverskiy Donets river basin. The river washes from the north, northeast and south and enters the central part of the village. That is, there are washing rocks. The Milova village has 6 streets. The development of the village is characterized mainly by one-two-storey homestead houses and 6 five-storey multi-apartment buildings, where the population working at Baltsem OJSC lives. The total population of the village is 1154 people. There is a school of I-III degrees, an art studio and a music school. Also in the village there is a plant of consumer services. All streets in the village are paved. However, there are very big problems in this picturesque village - two streets - Vysoka and Pidlisna are slipping, i.e there are very negative destructive processes - landslides. As a result of these negative processes, some residential buildings are constantly collapsing - cracks in the walls, sloping roof, cracks in the foundation, such houses 28. Drains are not designed on the street, but there is one $2 \mathrm{~m}$ wide, on both sides of which 2 deep ravines have already been created.

Space images and Public cadastral map of Ukraine with information layers (orthographic photo plan) gives an idea of the presence of exogenous processes, erosion hazard, soil degradation. You can quickly identify such areas and make a comprehensive assessment of the situation. Thus, from a space image, we found that the development of EGP is influenced by the presence of a water basin of the Siverskiy Donets River, the proximity of the quarry for the extraction of chalk, gas wells.

All these factors lead to soil instability, landslides due to flooding, constant earthquakes by mining equipment. The space image (Fig. 2) shows that the chalk quarry is located near the Milova village. Studies of the negative effects of exogenous and endogenous processes for 8 years show that the cause of landslides is the immediate vicinity of the quarry for the extraction of chalk, the proximity of the Siverskiy Donets river basin, the presence of unstable floating clay soils.

We photographed the landslide that was formed in a short time, the photo shows soil rocks - clay and chalk deposits (Fig. 5). Under the action of landslides, unfortunately, the Earth's crust collapses very quickly, creating failures. The action of raindrops during heavy rains destroys the surface, especially if there is a near water horizon.

With the help of data from the space base of the Earth, it is possible to quickly determine the boundaries of the studied areas, to determine the approximate geodetic coordinates of the studied areas, thereby reducing the time of surveys. To quickly respond and make management decisions on the further development of exogenous processes, it is necessary to have such information (Fig. 6).

In our study, we used: space images, cadastral map and rasters to compare areas and highlight boundaries.

It is possible to build a digital terrain model and draw the boundaries of regenerated areas using GIS technologies and remote sensing of the earth. The use of modern measuring 
systems and software makes it possible to identify such areas and display them in digital form (Fig. 7).

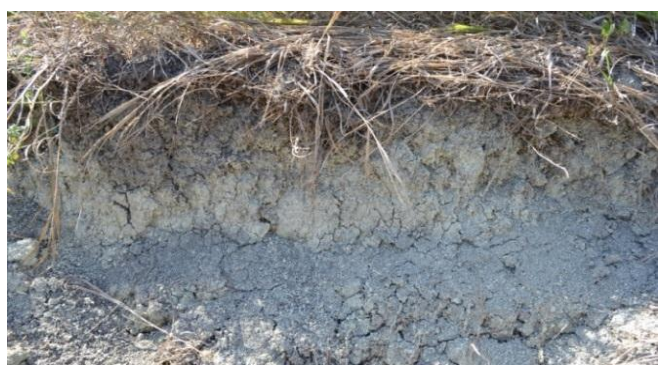

Fig. 5. Photo of the shift in Milova-Cretaceous deposits and clay soils are visible

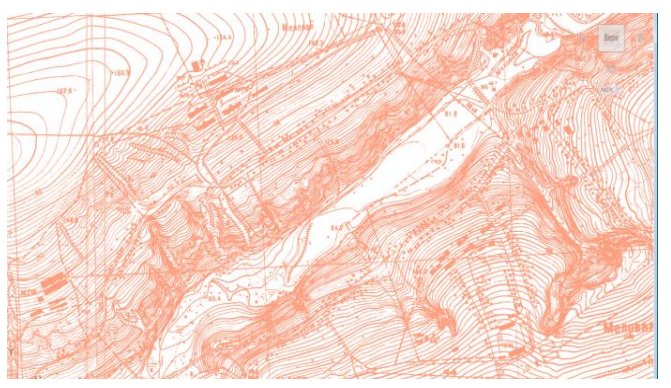

Fig. 6. Raster map of the territory of the Milova village

For this purpose it is necessary to carry out geodetic surveys by modern measuring systems, to process results by means of the software and to receive forecast decisions by modeling. We used national software Digitals to process the results of geodetic measurements and to build a digital map of landslides in Milova (Fig. 7).

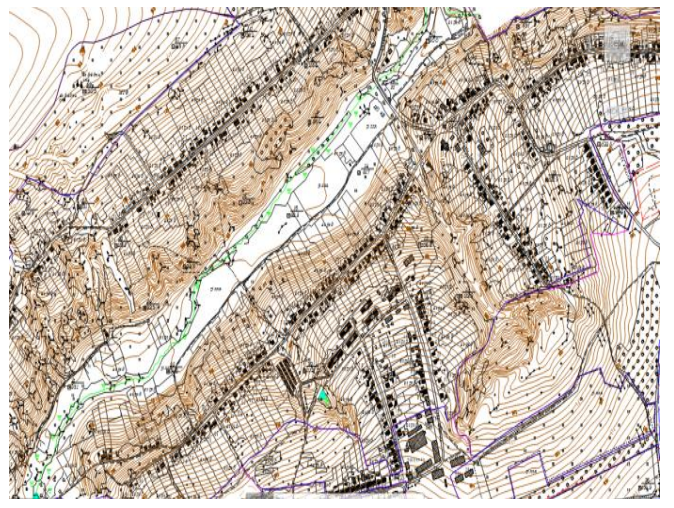

Fig. 7. The digital plan of EGP development is constructed

On the digital plane, we can see numerous landslides, dips, destruction, we can see the concentration of the horizontal, i.e the complex terrain, and in the center - the water body - the basin of the river S. Donets. It is seen that the action of the EGP destroys the streets, houses. For 8 years of our research and continuous observation it is revealed that the territory of EGP expanded (Fig. 8)

In the north-western part new landslides were formed, they became numerous. The depth has increased and the destruction of the streets has also, unfortunately, increased. Using computer software, we can predict the direction of water flows in a given array.

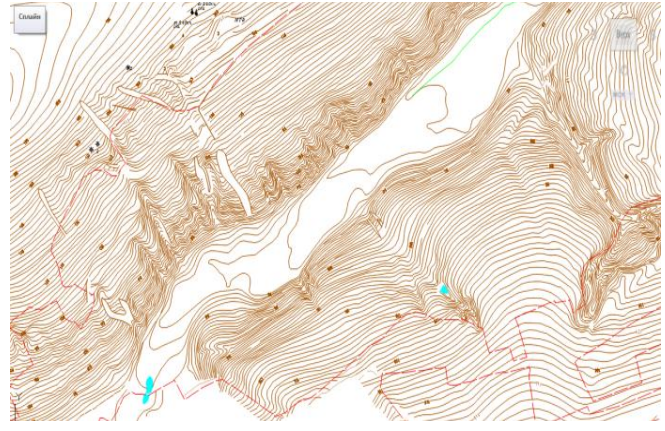

Fig. 8. Display of the line of monitoring of the problem of landslides $p$. Milova

Also, using a digital terrain model, we created a threedimensional model of the territory, which will help to understand the essence of the problem and draw conclusions about the improvement of the situation.

The digital terrain model makes it possible to see the direction of the watercourse lines, the distance between the horizontals and gives an idea of the relief and possible manifestations of erosion in those places where the relief and the thalweg line are lowered. Digital modeling can predict the intensity of the development of negative processes, setting different heights and possible leaching of the soil cover, which leads to soil buoyancy and, consequently, to the formation of landslides. Modeling the development of exogenous processes can prevent the negative consequences of the destruction of the earth's surface.

\section{Scientific novelty, practical activity}

Computer modeling of the development of landslide processes in the streets of residential and public land development within the village. Milova of Balakliia district of Kharkiv region gave the fact that the forecast effect of landslide processes for 5 years was developed. The simulation confirmed in which direction the landslide effect was projected and warned the leadership of the Milova village council - the village head and the Balakliya district state administration about the forecast landslide effect. As a result, the landslide was prevented by developing the "Project of anti-landslide organization of the territory" by designing a reinforcing engineering structure - a reinforced concrete structure on Vysoka and Pidlisna streets.

Fig. 9 is a fragment of the model of landslide development on Vysoka village. Milova in Digitals software, drawn horizontally using a space image of the EGP development area. The red dotted line indicates the shift and its subsequent action.

Digitals software allows us to simulate the shift development. For 3D modeling, which gives a threedimensional view, we need to periodically enter information about the effect of the shift. Thus, in our research for 8 years we entered the geodetic coordinates of the destroyed part of the earth's surface on the streets of the Milova village. These coordinates gave points of deviation from the original information, in the software Digitals noted differences in heights and built the development of the shear action in 3D format (Fig. 10). 


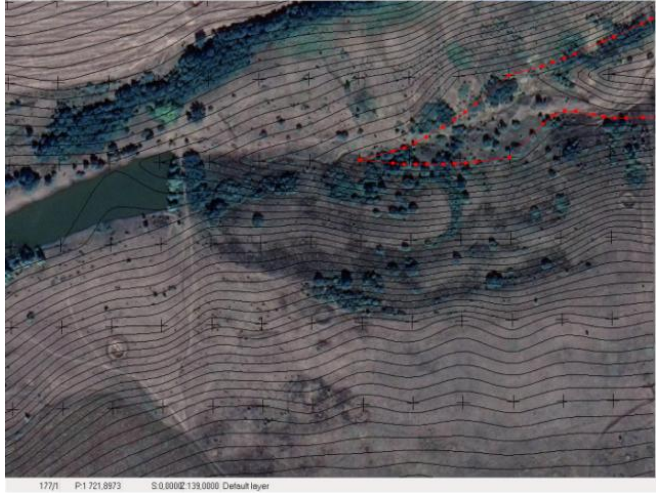

Fig. 9. Digital model of the development of shear action in a space image

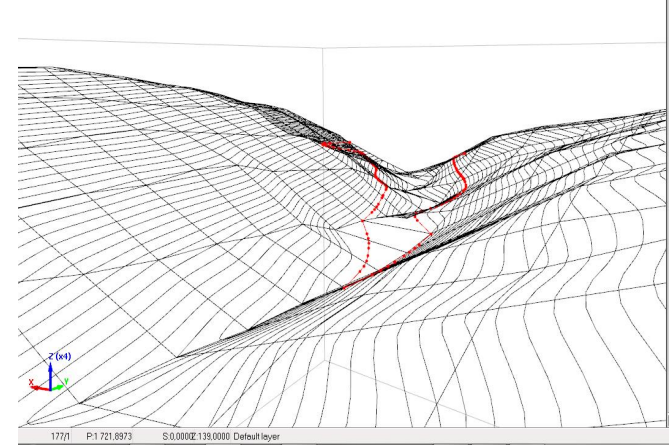

Fig. 10. 3D model of landslide development in the Milova village

On agricultural land outside the Milova village also had widespread negative EGP, which lead to constant loss of highvalue land. We predicted the development of negative processes and built models (Fig. 11-12).

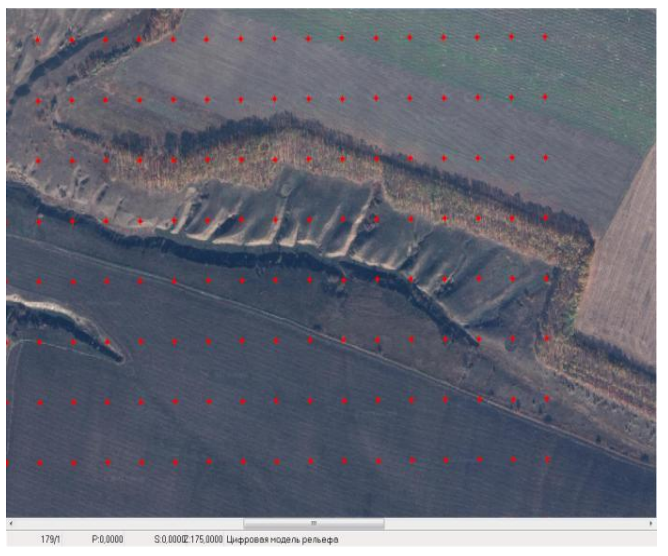

Fig. 11. Construction of a model for the development of dangerous exogenous processes on agricultural land

We entered the results of geodetic measurements after the implementation of geodetic surveying for 8 years - geodetic coordinates, elevation, displacement limits, which are constantly changing. With the help of software it was possible to build the development of negative exogenous processes. The program highlighted areas for modeling with red dots (Fig. 12).

With the help of GIS technologies, remote sensing of the Earth, it is possible to build models for the development of negative exogenous processes. The destruction of the soil cover can be predicted and predicted only to a small extent, unfortunately these processes are unpredictable.
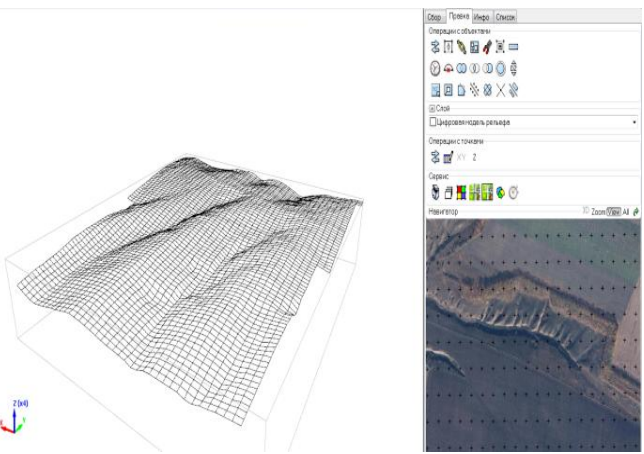

Fig. 12. Building a 3D model in Digitals

It is possible to prevent the development of EGP only partially, but it will also give results and possibly reduce the risk and negative effects of the destruction of the earth's surface for the population.

\section{Conclusions}

1. Conducted studies have shown that the development of exogenous processes in the forest-steppe zone of Kharkiv region is more common than in the steppe zone, because the groundwater level of the forest-steppe zone is higher than in the steppe zone.

2. Investigations have shown that the development of exogenous processes in the Milova village, Balakliya district, Kharkiv region, is influenced by the proximity of the chalk quarry, the Siverskiy Donets river basin and unstable clay soils.

3. The constructed models of EGP development give an idea of the further effect of negative processes. The dynamism and unpredictability of exogenous processes requires constant monitoring of their further development, identification of the projected affected area and possibly reducing the risk and adverse effects of land surface destruction for the population.

4. Building models for the development of exogenous processes can influence timely management decisions and reduce or avoid the negative destructive consequences and dangers of the population.

5. Monitoring of negative exogenous processes allows us to identify areas of danger, assess and predict the degree of geological risk.

\section{References}

Activation of dangerous exogenous geological processes according to EGP monitoring. Yearbook of Geoinform of Ukraine, issue XVII. Kyiv. 2020 (in Ukrainian).

Barthelmes, S., \& Köhler, W. (2012). International Centre for Global Earth Models (ICGEM). Journal of Geodesy, The Geodesists Handbook, 86(10), 932-934.

Bektaş, S. (2015). Geodetic computations on triaxial ellipsoid. International Journal of Mining Science, 1(1), 25-34.

Close, D. (2010). Isostasy and gravity modelling: Integrating potential field data in interpretation workflows. Official Publication of the Canadians Society of Exploration Geophysicists (CSEG RECORDER), 35(6). 
Kazachenko, L. M., Kazachenko, D. A. (2018). Advantages of GPS-technologies during development of projects of conservation of low-productive and degraded lands. Bulletin of $K h N T U$, issue 75 vol. 2 "Mechanization of agricultural production", p. 231-237 (in Ukrainian).

Kryvov, V. M. (2006). Ecologically safe land use of the foreststeppe of Ukraine. The problem of soil protection. Monograph. Kyiv: "Harvest". 301 p. (in Ukrainian).

Kuznetsov I., Rudko G. and other. (2005). Geological requirements for economic activity in landslide-prone areas. Simferopol.

Lushchyk A., Romanyuk O., Shvyrlo M. and other. (2005). Reporting materials of engineering-geological regime service (exogenous geological processes).

Medvedev, V. V. (2013). Physical degradation of chernozems. Diagnosis, causes, consequences, warnings. Monograph. Kharkiv: Publishing house City Printing House, 324 (in Russian).

Muratova M. (2019). Information report on monitoring, accounting for the spread and activation of exogenous geological processes within the territory of Kharkiv and Sumy regions for 2019.

Pylypenko, O. I., Yukhnovsky, V. Y., Vedmid, M. M. (2004). Soil protection systems against erosion. Textbook. Kyiv: Cultural and educational, publishing and printing center "Zlatoyar". 435 p. (in Ukrainian).

Rogister, Y., \& Valette, B. (2009). Influence of liquid core dynamics on rotational modes. Geophysical Journal International, 176(2), 368-388. https://doi.org/10.1111/ j.1365-246X.2008.03996.x.

Rudko G. (1995). Scientific and methodological bases of geological environment monitoring (engineering and geodynamic aspects). Ways to study the interrelated problems of the natural environment. Lviv.

Tserklevych A. L., Zayats O. S., Shylo Y. O. (2017). Dynamics of the Earth shape transformation. Kinematics and Physics of Celestial Bodies, Vol. 33, No. 3. P. 130-141 (Scopus). https://doi.org/10.3103/S0884591317030060.

Tserklevych A. L., Zayats O. S., Shylo Y. O., Shylo O. M. (2018). Generation of the stressed state of the lithosphere of the Earth and Mars caused by the reorientation of their figures. Kinematics and Physics of Celestial Bodies, Vol. 34, No. 1, pp. 19-36 (Scopus). https://doi.org/10.3103/ S0884591318010051.

Zaslavsky, M. N. (1983). Erosiology. Moscow: Higher school, $320 \mathrm{p}$.

\section{Людмила КАЗАЧЕНКО ${ }^{1}$, Владислав КАЗАЧЕНКО${ }^{2}$, Тетяна ЖИДКОВА ${ }^{3}$}

${ }^{1}$ Харківський національний автомобільно-дорожній університет, вул. Ярослава Мудрого, 25, Харків, 61002, Україна, https://orcid.org/0000-0001-7188-2790, e-mail: fop.kazacenko@ gmail.com), tel. 38 067-309-709-3.

${ }^{2}$ Харківський національний університет міського господарства ім. Бекетова, вул. Маршала Бажанова, 17, Харків, 61002, Україна, e-mail: kaza4enko.vlad@gmail.com, tel. 38 095-866-30-85

${ }^{3}$ Харківський національний університет міського господарства ім. Бекетова, вул. Маршала Бажанова, 17, Харків, 61002, Україна, e-mail: tavlz@ukr.net, id orcid 0000-0001-7903-7073, tel. 38 067-570-41-50

\section{ГІС-ТЕХНОЛОГІЇ ТА ЗD МОДЕЛЮВАННЯ У КАРТОГРАФУВАННІ ПРОЯВУ ЕКЗОГЕННИХ ПРОЦЕСІВ НА ВІДНОВЛЮВАНИХ ТЕРИТОРІЯХ}

Розвиток екзогенних процесів на поверхні Землі $є$ проблемою широкого масштабу. Завдяки розвитку екзогенних процесів відбуваються зміни у складі і структурі земної кори та ії поверхні. Руйнування вулиць, житлових будинків та громадських споруд, автомобільних доріг та залізниць призводить до колосальних втрат. Передбачити розвиток деградації грунтового покриву, ерозійних процесів на сільськогосподарських землях, які щорічно втрачають виробничі площі, що призводить до утворення яружно-балкової системи і зменшує продуктивну кількість земель, які перебувають у приватній власності громадян - $-\epsilon$ вирішенням проблеми. Застосування ГІС-технологій, Дистанційного зондування Землі і сучасного програмування частково може вирішити проблему, оскільки це швидке виявлення територій, що зазнали процесу деградації грунтового покриву та можливе прогнозування розвитку негативних явищ. Застосування геодезичного програмного забезпечення, ГІС, інформаційних шарів Публічної кадастрової карти може допомогти у якнайшвидшому знаходженні територій, розробленні прогнозу подальшої руйнівної дії, розробленні відповідних захисних методів іїх упровадженні. Нашим дослідженням були території з проявами екзогенних процесів - деградація грунтового покриву в с-г підприємствах, де кожен рік втрачаються площі високо родючих чорноземів, що призводить до великих збитків і зсуви в населених пунктах лісостепової та степової частини Харківської області. Ми дослідили руйнівні процеси шляхом геодезичних вимірів на територіях їх проявів, спостереження проводили на протязі 8 років. Виявлено розвиток екзогенних процесів на поверхні Землі, що проявлялося у зсувах в населених пунктах лісостепової зоні і деградації с-г земель на території степової та лісостепової частини Харківської області. Причиною руйнації земної поверхні були фактори, незалежні від людської діяльності. Ми побудували 3D моделі розвитку екзогенних процесів, що проявлялися в ерозії грунту й зростанні яружно-балкової системи, $\mathrm{i}$ визначили ступінь прояву ерозії після виконання знімання і оброблення результатів геодезичних вимірів у програмному забезпеченні Digitals. На протязі 8 років ми вносили зміни в програмне забезпечення, знімаючи територію і побудувавши лінію моніторингу. Також в населених пунктах на території двох зон ми вели спостереження за розвитком зсувів грунту на вулицях сіл Мілова та Нова Василівка, де відбувається інтенсивний розвиток екзогенних процесів. Застосування ГІС-технологій та дистанційного зондування Землі для ведення моніторингу розвитку екзогенних процесів спрощують вирішення проблеми.

Ключові слова: ГІС-технології; ДЗ3; відновлювані території; деградація грунтів; екзогенні та ендогенні процеси; просторові дані; руйнування 